\title{
Analysis of the Economic Potential for a Mercosur Rice Futures Market
}

\section{Análise do Potencial Econômico para Mercados Futuros de Arroz do Mercosul}

\author{
Waldemar Antonio da Rocha de Souza \\ Doutor em Economia Aplicada - USP/ESALQ \\ Professor Adjunto - FEAC/UFAL \\ Av. Lourival Melo Mota, S/N, Tabuleiro do Martins, Maceió/AL - 57072-970 \\ prof.wsouza@gmail.com \\ João Gomes Martines-Filho \\ $P h D$ em Economia Agrícola - Ohio StateUniversity \\ Professor Doutor - USP/ESALQ \\ Av. Pádua Dias, 11 - Piracicaba, SP - 13418-900 \\ martines@usp.br \\ Claudio Zancan \\ Doutor em Administração - UNB \\ Professor Adjunto - FEAC/UFAL \\ Rua Manoel Maia Nobre, 254, Apto 702 a - Farol, Maceió/AL - 57050-120 \\ claudiozancan@gmail.com \\ Antonio Carlos Silva Costa \\ Doutor em Psicologia - USP \\ Professor Titular - FEAC/UFAL \\ Av. Lourival Melo Mota, S/N, Tabuleiro do Martins - 57072-970 \\ acscosta@gmail.com \\ Andreza Galindo Alves de Queiróz \\ Mestranda em Administração Pública - FEAC/UFAL \\ Av. Lourival Melo Mota, S/N, Tabuleiro do Martins, Maceió/AL - 57072-970 \\ andrezagalindoalves@gmail.com
}

\begin{abstract}
World rice production reached 488.4 thousand tons, in 2012. Asian countries are the world's largest rice producers, followed by Latinamerica, particularly Brazil, where rice is a basic food item. In spite of the clear economic benefits bestowed by commodity futures markets, neither Asia nor Mercosur have implemented a regional rice futures market. In sum, we propose to investigate the feasibility of a Brazilian rice futures contract to serve the Mercosur region by estimating Mercosur rice price dynamics and analyze basis risk and hedging effectiveness for rice market agents in the region, in a simulation framework using a hypothetical regional contract price. Sample data and period was non-probabilistic, for accessibility and convenience. Mercosur rice price dynamics expressed Argentina and Uruguay rice prices moving in synchrony. Brazil rice prices were on lower levels. Also, all

Artigo publicado anteriormente nos Anais do $52^{\circ}$ Congresso da Sociedade Brasileira de Economia, Administração e Sociologia Rural - SOBER, 2014 e $3^{a}$ Conferência em Gestão de Risco e Comercialização de Commodities, 2013.

Artigo submetido em abril de 2015 e aceito em agosto de 2015 pela editora Fernanda Sauerbronn, após processo de double blind review.
\end{abstract}


three pairs of rice price series are cointegrated, with one cointegrating equation. Again, results can be largely attributed to the different price data used, in Brazil was rough rice, while in Uruguay and Argentina milled white rice with 5\%. Despite that, there are preliminary evidences that a Mercosur rice futures market could be feasible.

Keywords:Futures market; Rice; Risk management

\section{Resumo}

A produção mundial de arroz atingiu 488,4 mil toneladas, em 2012. Os países asiáticos são os maiores produtores de arroz, seguidos pela América Latina, particularmente o Brasil, onde o arroz é um alimento básico. Apesar dos claros benefícios econômicos alcançados pelos mercados futuros de commodities, nem a Ásia nem o Mercosul têm implementado um mercado futuro regional de arroz. Em suma, nos propomos a investigar a viabilidade de um contrato futuro de arroz brasileiro para servir a região Mercosul através da estimativa da dinâmica do preço do arroz no Mercosul e analisar o risco de base e a cobertura da eficácia para os agentes do mercado de arroz na região, em um quadro de simulação utilizando um preço hipotético de um contrato regional. Os dados da amostra e o período foram nãoprobabilísticos, por acessibilidade e conveniência. A dinâmica do preço do arroz no Mercosul expressa que os preços na Argentina e no Uruguai se deslocaram em sincronia. Os preços do arroz no Brasil estavam em níveis mais baixos. Além disso, todos os três pares de séries de preços do arroz são integrados entre si, com uma equação de co-integração. Mais uma vez, os resultados podem ser em grande parte atribuída aos diferentes dados de preços utilizados, no Brasil foi de arroz bruto, enquanto que no Uruguai e na Argentina arroz branco com 5\%. Apesar disso, existem evidências preliminares de que um mercado futuro de arroz no Mercosul poderia ser viável.

Palavras-chave: Mercados Futuros; Arroz; Gerenciamento de Risco.

\section{Introduction}

Rice is one of the most consumed staples worldwide and plays an important economic role in agricultural production. In fact, world rice production reached 488.4 thousand tons, in 2012. Asian countries are the world's largest rice producers, followed by Latinamerica, particularly Brazil, where rice is a basic food item.

Furthermore, average per capita rice consumption in Brazil was 48 kilos in 2012, classified in the subtropical group consumption bracket (MARION FILHO; EINLOFT, 2008). Besides, Brazil, Argentina, Uruguay and Paraguay, the Mercosur rice area, produced 10.1 thousand tons of rice in 2012. By comparison, the U.S. produced 6.3 thousand tons of rice in 2012 (OECD-FAO, 2013).

Despite the U.S. comparatively lower rice production than Mercosur; there is an active long-grain rough rice futures market, which began trading in1986. McKenzie et al (2002) concluded that the U.S. rough rice futures market was efficient. The results were relevant to price discovery and price risk management decisions of U.S. rice industry agents, highlighting rice futures markets economic role.

In spite of the clear economic benefits bestowed by commodity futures markets, neither Asia nor Mercosur have implemented a regional rice futures market. In Asia, rice cash market characteristics, government intervention, lack of quality and grading standardization were not conducive to the innovation of a regional rice futures contract (McKENZIE, 2012). In contrast, initial research has painted a more positive picture about the feasibility of a rice 
futures market in Brazil (COSTA; COELHO; MIRANDA; LÍRIO, 2010; CAPITANI; MATTOS, 2013). Nevertheless, further research is required to determine the likely success of a Brazilian rice futures market. Given that Brazil is the largest importer of Argentinean and Uruguayan rice (MARION FILHO; EINLOFT, 2008), it is vital to assess rice price dynamics and linkages within the Mercosur region as a whole and so determine basis risk and hedging effectiveness for potential hedgers across the region. .

In sum, we propose to investigate the feasibility of a Brazilian rice futures contract to serve the Mercosur region by i. estimating Mercosur rice price dynamics, linkages; and, ii. analyze basis risk and hedging effectiveness for rice market agents in the region in a simulation framework using a hypothetical regional contract price.

Next section illustrates the literature review. Follows the methods and data section, results and discussion.Lastly the research summary and conclusions.

\section{Literature Review}

There is a large body of literature about the success and failure of futures markets. The futures markets economic and operational features have been analysed to determine the underlying causes for feasibility. Particurlarly for agricultural commodities, for example rice, several researchers have summarized futures contracts operational feasibility, identifying economic issues about the functions of futures markets.

To illustrate, Gray (1966) indicated reasons for futures markets success and failure. To be successful a futures market must attract hedging and speculative operations. On the other hand, reasons for failure were poor contract design, market power and failure to attract speculation. Equally importante were the government role in the markets and commodity storability.

Working (1970) explained that any futures market succeeded only if it could attract hedgers. Additional necessary conditions for success were the attraction of merchandising purposes and speculation, temporary substitution for merchandisers and public recognition of the economic usefulness of the futures market.

Telser and Higinbotham (1977) formulated an analytical framework to evaluate the costs and benefits of organized futures markets, that could be applied to other organized markets. Demonstrated that an organized market facilitates trade among strangers. It creates a homogeneous good that can be traded anonymously by the participants or their agents. The benefit of an organized market is an increasing function of the number of potential participants.

Also, it is an increasing function of the turnover of the potential participants in that market. Transactions prices alone convey a considerable amount of useful information to those who are not currently trading in the market. Price variability affects the benefit of having an organized market and the cost. There is more price variability for those goods that have an organized futures market than for the goods that lack such markets. It does not follow that futures trading causes greater price variability. In addition, the volume of trade increases relative to the open interest.

Carlton (1981) analyzed the historical perspective of futures markets. Summarized that organized futures markets provide a low-cost risk transfer mechanism, where people with different beliefs can speculate. Also, forward markets are not perfect substitutes for organized futures markets and private gains for organizers and social gains are not the same. Besides, there is no need for special regulation, since futures markets are another type of competitive market.

Peck (1985) explained that the economic benefits of futures markets were the process of price discovery, rationalization of storage decisions, hedging of storage and provision of 
antecipatory prices, guiding the optimal allocation of resources to the production and consumption of commodities by production, processing and marketing firms.

Cuny (1993) developed a model of market innovation in which exchanges compete to be able to share the risk of the hedgers. Exchanges choose the contract and number of investors who enter, and entry fee estimating market structure, contracts and investors in other markets. An exchange optimizes by offering contracts to fill hedging demand not met by other exchanges and using monopoly power to limit investor entry by keeping high fees.

Equally important is the introduction of futures markets in thin markets, particurlarly in less developed countries. Leuthold (1994) evaluated the economic preconditions for creating new futures and options markets in various countries, assessing the benefits and costs of establishing such domestic futures markets as opposed to using existing futures markets in developed countries. Macroeconomic preconditions are the need for property ownership, trading and traders, price risk, regulation, risk capital, information, communication, and a means to assure integrity. The microeconomic preconditions are that hedgers and speculators must be knowledgeable and trained. The exchange needs an associated clearinghouse for the financial backing of contracts and guaranteeing of transactions. And there needs to exist a clear set of trading rules and procedures, enforceable through a legal system.

Morgan, Rayner and Vaillant (1999) compared the costs, potential advantages and disadvantages between establishing domestic futures markets and using existing exchanges in developed markets economies. The latter is cheaper and quicker but produces problems of basis and exchange risk. The former does not bear these risks but is very expensive and potentially a long-run policy option only. Other necessary pre-conditions are a well defined legal and regulatory system supported by a well developed financial sector, besides education and training in the case of establishing domestic markets.

Peck (2001) analyzed the history of the commodities exchanges in the centrally planned economies of the countries of the former Soviet Union and China. Most of the new exchanges have since closed either for lack of activity or by government intervention, identifying numerous obstacles, from developing standardised contract terms to establishing effective self-regulation and state regulatory oversight.

In several countries, the transparency of transactions on exchanges attracted governments interested in collecting taxes and customs duties which only drove trade away from the exchanges or turned them into mere state agencies. In China, regulators struggled with duplicative exchanges and products, price volatility, large speculative interest, and several manipulations, reducing the number of exchanges and severely limited the commodities traded. However there have been some successes in China, Hungary and Poland.

Pennings and Leuthold (2001) analyzed the beneficies to add new futures contracts to those already listed from a futures exchange management perspective. The futures exchange must study the effects introducing new contracts on those futures contracts already listed, avoiding the possibility of cannibalism. Also, the exchange must investigate the hedger's underlying input-output portfolio, the agent's residual spot market risk, before introducing new futures contracts.

Johnston and McConnell (1989) analyzed the failure of the financial GNMA GDR futures contract. Concluded that the GNMA GDR futures contract showed flaws in its design. In particular, the delivery alternatives diminished its hedging effectiveness, since the Treasury bond futures provided a better hedge for the underlying asset.

Silber (1981) assessed the innovations in futures contracts, particurlarly the development of competitive futures contracts and the consequences of such contract proliferation for the individual exchange and for economic welfare. Three specific issues have 
been identified as main points, the role of competition as a force for innovation, costs and benefits of new contract design and the role of regulation.

Brannen e Ulveling (1984) compared how well current spot prices predict future spot prices for a variety of commodities in a non-futures market environment, examining how the predictive power of the price system is altered after the initiation of futures trading. There are a positive association between the inability of a non-futures market price system to predict the future spot price and the subsequent development of a futures market. Also, traders can earn a return on information collection after the introduction of a futures price into the pricing system is supported for some, but not all, commodities.

Tashjian (1995) described the characteristics of successful futures contracts implied by the design literature, relating the observations to empirical studies. Besides, expressed how the design literature can be applied to reveal the link between the specific terms of successful futures contracts to charactetics of the cash market. The determinants of contract success are hedging demand, cash market characteristics, asymmetries in characteristics of long and short participants and competing contracts.

Furthermore, modelling contract form must estimate the precise terms of the new futures contracts. In particular, if the futures contract is cash or commodity settled and how and when does delivery occur. In addition, the exchange must decide what clientele its products will serve and tailor the new contracts accordingly. If the exchange wishes to act as a matchmaker between two large investment banks, then innovation should come in the form of developing flexible products to increase hedging effectiveness. If, instead, the exchange wants to provide liquidity to a large group of investors, products should be designed to appeal to both hedgers and speculators.

Brorsen and Fofana (2001) estimated the effects of several factors on the success or failure of agricultural futures contracts. Commodities with futures markets and without futures markets were analyzed and characteristics for which no data exist, such as homogeneity, vertical integration, buyer concentration, and activeness of the cash market, were measured by the Delphi approach. An active cash market is found to be a necessary condition for futures contract success. The cash market size is the best predictor whether or not a commodity has a futures market.

Sandor (1973) summarized how major commodity exchanges have researched and developed new and successful contracts, studying the development of the plywood contract on the Chicago Board of Trade. The inventive process can be divided into two distinct stages. The first part examines established criteria to determine whether or not the commodity can be adapted to futures trading and preliminary aspects of contract provisions.

The second stage includes an initial drafting of the contract and its subsequent convergence to the form existent when trading commences. Also, a post-introduction changes in specifications intended to broaden contract appeal. The activity is characterized by interactions among professional exchange staff, exchange members and advisory groups who are commercial users of the market. The plywood futures resulted in the establishment of a Research and Development department in the exchange.

Sanders and Manfredo (2002) examined the performance of the Minneapolis Grain Exchange's white shrimp futures contract, one of the first futures contracts aimed at the aquaculture industry. Although the market structure largely conformed to the traditional criteria for a successful futures market, the contract's performance was disappointing in terms of liquidity, basis behavior and hedging effectiveness. Furthermore, nonpar-size delivery options embedded in the contract design likely impact basis behavior for certain hedges. Also, a negative factor was the lack of knowledge regarding futures markets among the shrimp industry. 
Recently, Bekkerman and Tejeda (2013) analyzed the failure of the distillers' dried grain (DDG) contract launched on 2010 at the CME GROUP. Examined the market factors determining the success of potential futures contracts and their role in affecting the demand for existing futures contracts.Also, developed an empirical method for estimating the activeness of cash markets, a conceptual framework that demonstrates the potential importance of support markets for commodities that are produced in fixed proportion with other goods.

In addition, provided empirical evidence that active support markets are the most important factor in predicting futures contract trade volume of co-products. Particularly, the role of support market participants partly helps explain the rapid failure of the DDG futures contract, which was met with mixed feelings by the industry.

Moreover, several authors assessed different geographical futures markets. Hung et al (2011) examined key factors that influence the success of exchange-traded futures contracts of Asian futures markets. Successful futures contracts benefit from a large and volatile spot market. In addition, a smaller contract size has a positive effect on the futures trading volume, which in turn contributes to the success of the futures contract. For specific institutional factors, the choice of the trading platform and the relative size of exchanges are both important to the success of futures contracts.

Siqueira, Silva and Aguiar (2009) analyzed the viability of introducing a milk futures contract in Brazil as a tool for managing price risk. The chilled raw milk had the best potential for futures trading in Brazil. Additionally, an investigation of a profile of the largest Brazilian milk producers and a consultation process with other industry stakeholders also showed favorable characteristics and attitudes regarding the introduction of futures trading.

Quintino and David (2013) analyzed the main requirements for the viability of the BM\&FBovespa ethanol futures contract, particularly the ethanol spot prices volatility, the correlation between futures and spot prices, the cross-hedge effectiveness and the degree of market concentration. All features were favorable, except a high degree of market concentration.

In addition, in the case of rice, Zacharias et al (1987) examined the cross-hedge between spot rough rice prices using wheat futures contracts in the U.S. Results showed that there was potential effectiveness for the cross-hedge as a marketing alternative at farm-level.

Also, McKenzie et al (2002) examined the short-run and long-run unbiasedness within the U.S. long grain rough rice futures market. Standard OLS, cointegration, and errorcorrection models were used to determine unbiasedness, analyzing the forecasting performance of the rice futures market. Results showed that the U.S. rice futures market was efficient.

Specifically for the Asia rice market, McKenzie (2012) discussed the prefeasibility study of a rice futures market in the Association of Southeast Asian Nations (ASEAN) region. An ASEAN-based rice futures contract would provide two important economic benefits to the market: price discovery and price risk management. However, current cash market characteristics were not conducive to the development of a successful rice futures contract at either the domestic or regional level.

Concerning the Mercosur rice market, Marion Filho and Einloft (2008) evaluated the competitiveness of irrigated rice produced in Brazil, Uruguay and Argentina. Argentina is the most competitive of the region, due to the lower production costs per hectare and per bag of $50 \mathrm{~kg}$, followed by Uruguay and Brazil. In Brazil policies are oriented towards rural credit and short term actions, with reduced subsidies for large scale farmers and protection of family agriculture. 
In Uruguay, the agricultural policies are centered on research, rural assistance, campaigns against diseases and plagues and inspection services, with rural financing predominantly in US dollars with market interest rates. In Argentina, the farmers are inserted in a market economy without state subsidy. Also, the changes in the exchange policy and the alterations in the Mercosur common external tariff (TEC) affect the prices and are prejudicial to competition.

Moreover, for the Brazilian rice market, Adami and Miranda (2011) evaluated the price dynamics in the domestic market of paddy rice to define the process of prices formation and the adjustment intensity among the major producing markets, Rio Grande do Sul and MatoGrosso states, using vector error correction - VEC and Granger's causality models. Results showed that Rio Grande do Sul prices are important to forecast prices in MatoGrosso.

Finger and Waquil (2013) analyzed how rice farmers in FronteiraOeste, Rio Grande do Sul assessed the risks of their activity and how they managed them. The results indicated that rice farmers attach greater relevance to economic and social risks rather than to production related ones. Thus the importance of business management, in order to integrate their activity with others links of the production chain was distinguished. Also, costs reduction may be an option to mitigate market risks, identified as the most relevant by the rice growers.

Miranda et al (2007) proposed a sketch of the chain structure for the Brazilian South rice sector and characterized its main agents, describing the forms of coordination between the growers and the processors, even cooperatives. Other Brazilian states rice production systems and commercialization channels were identified. Concluded that the relevance of Rio Grande do Sul's rice production and of the Southeast retail segment for understanding the prices dynamics. Also relevant were the trademarks for the regional and national supply, the industrial concentration process, the lackness of a formal contractual relationship between producers and processors and the necessity of a better balance between Brazilian rice exports and imports, particularly focused on the possibilities to increase exports.

With regard to the Brazilian rice futures market feasibility, Costa et al (2010) evaluated the feasibility of introducing a rice futures market as a tool to mitigate price risk. Applying the theory of success and failure of futures markets, concluded that a term market should be implemented to agents develop their knowledge and potential prior to the futures market. Also, government intervention in the price system must be reduced and industrial concentration could dampen the futures market effectiveness. Besides irrigated and dry rice markets were integrated and Rio Grande do Sul was the leading rice price maker in Brazil.

Capitani (2013) and Capitani and Mattos (2013) concluded that a rice futures market for Brazil was feasible. Evidences were low cross-hedge effectiveness, diminishing government intervention and an existing rice price index, based in Rio Grande do Sul prices, comprising $75 \%$ of domestic production.

However, despite the research on international and Brazilian rice futures markets feasibility, there are not studies about a Mercosur rice futures market, which is the distinct contribution of the research.

\section{Methodology and data}

\subsection{Mercosur rice price dynamics and linkages}

The estimation of Mercosur rice price dynamics and linkages will use the Johansen cointegration framework and Granger vector error correction model (VECM) for short and long-term causality. 


\subsubsection{Johansen cointegration}

If the time series are non-stationary then cointegration can be used to evaluate if there is a statistically significant relationship between the time series. The first step is to test the stationarity of the time series in levels and in first differences.

If the price series are integrated of order one are denoted $\beta \mathrm{Pt} \sim \mathrm{I}(1)$. Similarly, if prices are integrated of order zero are denoted by $\Delta \mathrm{Pt} \sim \mathrm{I}(0)$. If prices series are non-stationary in levels but are stationary in first differences, cointegration tests may be used.

The cointegration framework is based on na unrestricted vector autoregressive (VAR) model specified in error-correction form (JOHANSEN, 1988; JOHANSEN, JUSELIUS; 1990):

$$
\Delta X_{t}=\Pi X_{t-1}+\sum_{i=1}^{k-1} \Gamma_{i} \Delta X_{t-i}+\phi D_{t}+v_{t}
$$

Where Xt describe all $\mathrm{n}$ variables of the model which are $\sim \mathrm{I}(1)$;

$\Pi, \Gamma_{i}$ e $\phi$ are parameters matrices to be estimated;

$\mathrm{Dt}$ is a vector with constant, trend and dummy, the deterministic elements;

$v t$ is a vector of random errors following a Gaussian white noice process.

By Eq. (1) there can never be any relationship between a variable with a stochastic trend, I(1) and another without a stochastic trend, $\mathrm{I}(0)$. Therefore, if $\Delta \mathrm{Pt} \sim \mathrm{I}(0)$ then $\Pi$ will be a matrix of zeros, except for a linear combination of the variables in Pt is stationary.

The Johansen test for cointegration assesses the rank ( $r$ ) of the matrix $P$. If $r=0$, all variables are $\mathrm{I}(1)$ and not cointegrated. If $0<\mathrm{r}<\mathrm{N}$, there exists $r$ cointegrating vectors. If $r=$ $\mathrm{N}$ all the variables are $\mathrm{I}(1)$ and stationary and any combination of stationary variables will be stationary. $\Pi$ is the long response matrix, resulting from the product of two matrices $\alpha$ and $\beta^{\prime}$, of dimension ( $\mathrm{g} \times \mathrm{r}$ ) and ( $\mathrm{r} \times \mathrm{g}$ ), respectively.

The matrix contains the long-run coeficientes of the cointegrating vectors and $\alpha$ is known as the adjustment parameter matrix and is similar to an error correction term. The linear combination(s) $\beta^{\prime} \mathrm{xt}-\mathrm{k}$ of this matrix will be $\mathrm{I}(0)$ in the case where the times series are cointegrated. In other words, if rank of $\Pi=\mathrm{r}=\mathrm{K}$, the variables in levels are stationary meaning that no integration exists. If rank of $\Pi=r=0$ it identifies that all the elements in the adjustment matriz have zero value and no linear combinations are stationary.

By Granger representation theorem (ENGLE; GRANGER, 1987a), when K>0 and rand of $\Pi(\mathrm{r})<\mathrm{K}$, there are $\mathrm{r}$ cointegrating vectors or $\mathrm{r}$ stationary linear combinations of the variables. The Johansen cointegration method estimates the П matrix using an unrestricted VAR and tests if the restriction of the reduced rank of $\Pi$ can be rejected.

There are two methods for testing the reduced rank of $\Pi$, the trace test and the maximum eigenvalue:

$$
\begin{aligned}
& \lambda_{\text {trace }}=-T \sum_{i=r+1}^{n} \ln \left(1-\lambda_{i}^{2}\right) \\
& \lambda_{\text {max }}(r, r+1)=-T \ln \left(1-\lambda_{r+1}\right)
\end{aligned}
$$

Where $\lambda \mathrm{i}$ is the estimated values of the ordered eigenvalues obtained from the estimated matrix and $\mathrm{T}$ is the number of the observations after the lag adjustment. The trace statistics test the nul hypothesis that the number of distinct cointegrating vectors ( $r$ ) is less than orequal to $r$ against a general alternative. The maximal eigenvalue tests the null that the number of cointegrating vectors is $r$ against the alternative of $r+1$ cointegrating vectors. 


\subsubsection{Vector error correction model (VECM) for causality}

If the bi-variate relationship records cointegration, then there exists Granger causality at least in one direction. Under certain restrictions the Granger causality can be tested within the framework of Johanssen cointegration using the Wald test (DOLADO; LUTKEPOHL, 1996; MOSCONI; GIANNINI, 1992).

If the $\alpha$ matrix in the cointegration matrix (П) has a complete column of zeros, no casual relationship exist since no cointegrating vector appears in that particular block. Pair wise causal relationship can be represented through the equation:

$$
\left[\begin{array}{c}
\Delta X_{1, t} \\
\Delta X_{2, t}
\end{array}\right]=\left[\begin{array}{l}
\mu_{1} \\
\mu_{2}
\end{array}\right]+\left[\begin{array}{l}
\alpha_{1} \\
\alpha_{2}
\end{array}\right]\left(X_{1, t-1}-\beta X_{2, t-1}\right)+A_{1}\left[\begin{array}{c}
\Delta X_{1, t-1} \\
\Delta X_{2, t-1}
\end{array}\right]+\ldots A_{k}\left[\begin{array}{c}
\Delta X_{1, t-k} \\
\Delta X_{2, t-k}
\end{array}\right]+\left[\begin{array}{c}
v_{1 t} \\
v_{2 t}
\end{array}\right]
$$

The parameters of matrices Ak illustrate the short run causality relationship, while $\beta$ is the cointegrating parameter that characterizes the long run equilibrium relationship between the series.

In Eq. (4) three possibilities for long-run causality may be identified:

$$
\begin{aligned}
& \alpha_{1} \neq 0, \alpha_{2} \neq 0 \\
& \alpha_{1}=0, \alpha_{2} \neq 0 \\
& \alpha_{1} \neq 0, \alpha_{2}=0 .
\end{aligned}
$$

The first case identifies bi-directional causality, and the second and third illustrate unidirectional causality.

To analyze for short-run causality the Wald test is applied with the null hypothesis that the joint contribution of the lags of the endogenous variables is equal to zero. If the null cannot be rejected it implies that the respective endogenous variables can be treated as exogenous in the system.

In case of bi-variate models, the Johansen cointegration Eq. (1) can be rewritten as:

$$
\begin{aligned}
& \Delta X_{1, t}=\mu_{1}+\sum_{i=1}^{k 1} \beta_{i} \Delta X_{1, t-i}+\sum_{j=1}^{k 2} \beta_{j} \Delta X_{2, t-j}+\alpha_{1} \mathrm{ECT}_{t-1}+\varepsilon_{t, 1} \\
& \Delta X_{2, t}=\mu_{2}+\sum_{i=1}^{k 1} \beta_{i} \Delta X_{1, t-i}+\sum_{j=1}^{k 2} \beta_{j} \Delta X_{2, t-j}+\alpha_{2} \mathrm{ECT}_{t-1}+\varepsilon_{t, 1}
\end{aligned}
$$

Where:

$\mathrm{X} 1, \mathrm{t}$ and $\mathrm{X} 2, \mathrm{t}$ are price time series and ECT is the error correction term. The short-run causality is tested usinqEqs. (5) and (6), examining the significance of all lagged dynamic terms.

\subsection{Analyze basis risk and hedging effectiveness for rice market agents in the region in a simulation framework using a hypothetical regional contract price}

Following Capitani (2013), will use the CEPEA rice index as proxy for a hypothetical rice futures contract for Mercosur.

\subsubsection{Basis risk}

The basis indicates a commodity spot price relationship with its futures prices, as per the equation (LEUTHOLD; JUNKUS; CORDIER, 1989): 
$\mathrm{B}=\mathrm{S}-\mathrm{F} \quad$ (Eq. 1)

Where $\mathrm{B}=$ basis, $\mathrm{S}=$ commodity spot price at a specific location, $\mathrm{F}=$ nearest maturity future contract price.

There is basis risk whenever a commodity portfolio holds a simultaneous spot and futures position. We will use the variation coefficient for the preliminary Mercosur rice basis risk measurement.

\subsubsection{Minimum variance hedge model and hedging effectiveness}

For Hull (2012) the optimal hedge ratio describes the futures and spot markets position of an agent that minimizes price variance if he is a risk averter. This ratio is given by:

$$
\frac{\operatorname{COV}\left(\Delta S_{t}, \Delta F_{t}\right)}{\operatorname{Var}\left(\Delta F_{t}\right)}
$$

where:

$\Delta S_{t}=$ spot prices first difference;

$\Delta F_{t}=$ futures prices first difference.

Leuthold et al. (1989) showed that these variables are calculated through the ordinary least squares (OLS) estimation of:

$$
\Delta S_{t}=\alpha+\beta \Delta F_{t}
$$

where:

$\alpha, \beta=$ are linear parameters of the model.

In equation 2 the estimated $\beta$ indicates the total output ratio that should be traded in the futures markets yielding the least variance, the minimum variance optimal hedge ratio. The standard coefficient of determination $-R^{2}-$ in the OLS models, indicates the hedging effectiveness, the decrease in the price variance of the agent's total position, given by the sum of his spot and futures markets positions (HULL, 2012).

Therefore first differences of rice spot prices in Brazil, Argentina and Uruguay will be regressed with the first differences of the CEPEA rice index, all denominated in US dollars for metric tons.

\subsection{Data}

Sample data and period was non-probabilistic, for accessibility and convenience. Four sets of rice prices were used:

Tab. 1.Prices used, specification and source.

\begin{tabular}{l|l|l|l} 
Price & Specs & Source & Website \\
\hline \multirow{5}{*}{$\begin{array}{l}\text { Brazil } \\
\text { spot }\end{array}$} & $\begin{array}{l}\text { Proxy for Brazilian spot rice } \\
\text { prices are end of month rice } \\
\text { prices in Depressão Central } \\
\text { (RS), the largest rice } \\
\text { harvested area in Rio Grande } \\
\text { do Sul; RS is Brazil's main } \\
\text { rice producer }\end{array}$ & $\begin{array}{l}\text { Special } \\
\text { request to } \\
\text { INSPER (SP) }\end{array}$ & www.insper.edu.br \\
\hline $\begin{array}{l}\text { Argentina } \\
\text { spot }\end{array}$ & $\begin{array}{l}\text { Arroz branco, preços FOB, } \\
\text { tipo 5\% }\end{array}$ & INFOARROZ & $\begin{array}{l}\text { lploadfiles } \\
\text { /20131105150349_28_pre } \\
\text { cios_mercosur.htm }\end{array}$
\end{tabular}




\begin{tabular}{l|l|l|l}
$\begin{array}{l}\text { Uruguay } \\
\text { spot }\end{array}$ & $\begin{array}{l}\text { Arroz branco, preços FOB, } \\
\text { tipo 5\% }\end{array}$ & INFOARROZ & $\begin{array}{l}\text { www.infoarroz.org/portal/ } \\
\text { uploadfiles } \\
\text { /20131105150349_28_pre } \\
\text { cios_mercosur.htm }\end{array}$ \\
\hline $\begin{array}{l}\text { Mercosur } \\
\text { futures }\end{array}$ & Indicador CEPEA & CEPEA & www.cepea.esalq.usp.br
\end{tabular}

Note: Period from Jan 2006 to Oct 2013.

Source: Calculations were performed by the author.

\section{Results discussion}

The first step was the estimation of Mercosur rice price dynamics, linkages.

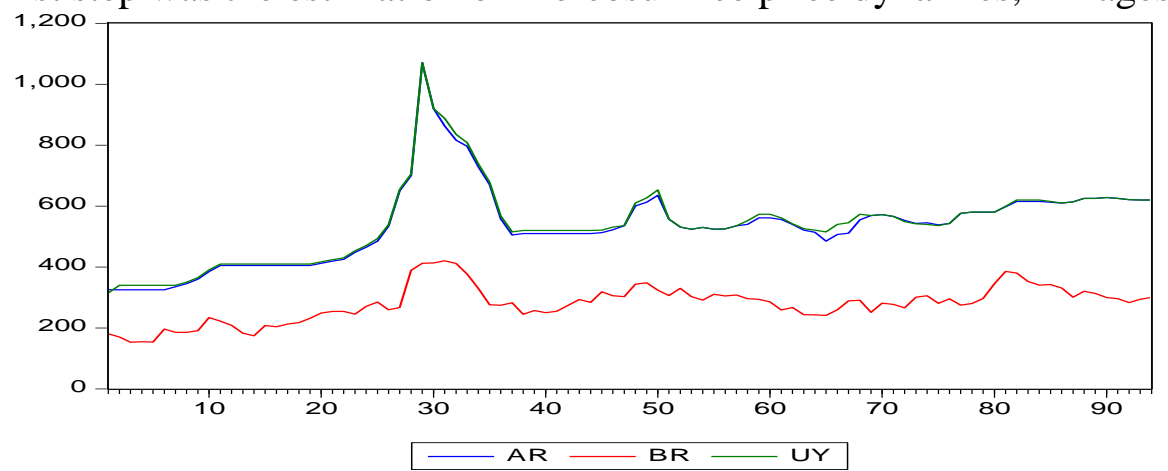

Graph 1.Mercosur price series in levels.In US\$/metric ton.Jan/2006 to Oct/2013.

Graph 1 shows prices that Argentina and Uruguay rice moving in synchrony. Brazil rice prices on lower levels. Differential due to sourcing and rice types.

Tab. 2.Unit root tests using the Augmented Dickey-Fuller (ADF) and Phillips-Perron (PP).

\begin{tabular}{|ccccc|}
\hline Price & ADF Drift & ADF & PP & PP \\
& & Trend & Drift & Trend \\
Brazil & -2.3214 & -2.3698 & -2.4599 & -2.6005 \\
$\square$ Brazil & $-8.4444^{*}$ & & $-8.4498^{*}$ & \\
Argentina & -2.2121 & -2.2377 & -2.4404 & -2.5452 \\
$\square$ Argentina & $-9.0448^{*}$ & & $-9.0901^{*}$ & \\
Uruguay & -2.8990 & -3.0497 & -2.5117 & -2.5720 \\
$\square$ Uruguay & $-5.0823^{*}$ & & $-9.2648^{*}$ & \\
\hline
\end{tabular}

Source: Calculations were performed by the author.

Obs.: Lag length for ADF tests based on SIC. Maximum bandwidth for PP tests are decided based on Newey and West (1994). Critical values are -2.886 (5\%), -3.486 (1\%) with drift only; $-3.447(5 \%)$ and $-3.486(1 \%)$ for the model with constant and trend; and, 1.943 $(5 \%)$ and $-2.584(1 \%)$ for the pure random walk model, indicated by $(*)$.

Therefore, all 3 rice price series in level have unit roots and are I(1). The first differences are stationary, I (0). Therefore, the Johansen cointegration framework can be applied. 
Tab. 3. Bi-variate Johansen cointegration rank test.

\begin{tabular}{|c|c|c|c|}
\hline Equation & Test statistics & $\begin{array}{l}\text { Critical } \\
\text { values }\left(\lambda_{0,95}\right)\end{array}$ & Decision \\
\hline \multicolumn{4}{|l|}{$\begin{array}{l}\text { Braziland Argentina } \\
(\mathrm{k}=2 \text {; criteria: } \mathrm{LR})\end{array}$} \\
\hline $\begin{array}{l}\lambda_{\text {trace }} \\
\mathrm{H}_{0}: \mathrm{r}=0 \text { vs } \mathrm{H}_{1}: \mathrm{r} \geq 1\end{array}$ & 12.5133 & 12.3209 & Rejected \\
\hline$\lambda_{\max }$ & & & \\
\hline $\begin{array}{l}\mathrm{H}_{0}: \mathrm{r}=0 \text { vs } \mathrm{H}_{1}: \mathrm{r} \geq 1 \\
\text { BrazilandUruguay } \\
(\mathrm{k}=3 \text {; criteria: } \mathrm{LR})\end{array}$ & 12.5078 & 11.2248 & Rejected \\
\hline $\begin{array}{l}\lambda_{\text {trace }} \\
\mathrm{H}_{0}: \mathrm{r}=0 \text { vs } \mathrm{H}_{1}: \mathrm{r} \geq 1\end{array}$ & 12.6889 & 12.3209 & Rejected \\
\hline$\lambda_{\max }$ & & & \\
\hline $\mathrm{H}_{0}: \mathrm{r}=0$ vs $\mathrm{H}_{1}: \mathrm{r} \geq 1$ & 12.6814 & 11.2248 & Rejected \\
\hline $\begin{array}{l}\text { Argentina andUruguay } \\
(\mathrm{k}=3 \text {; criteria: } \mathrm{LR})\end{array}$ & & & \\
\hline$\lambda_{\text {trace }}$ & & & \\
\hline $\mathrm{H}_{0}: \mathrm{r}=0$ vs $\mathrm{H}_{1}: \mathrm{r} \geq 1$ & 13.3119 & 12.3209 & Rejected \\
\hline$\lambda_{\max }$ & & & \\
\hline $\mathrm{H}_{0}: \mathrm{r}=0$ vs $\mathrm{H}_{1}: \mathrm{r} \geq 1$ & 13.2988 & 11.2248 & Rejected \\
\hline
\end{tabular}

Note: Rejection of H0 identifies one cointegrating equation.

All three pairs of rice price series are cointegrated, with one cointegrating equation.

Therefore, there exists a linear combination of the series that is stationary identified by a long term nonzero vector, the cointegrating vector.

Tab. 4.Estimates of long run and the speed of the adjustment from ECM. No trend or intercept in VAR.

\begin{tabular}{llll}
\hline Equation & Regressors & $\begin{array}{l}\text { Parameter } \\
\text { estimates }\end{array}$ & t-test \\
\hline \multirow{2}{*}{ Brazil-Argentina } & $\beta$ & $-0.3062^{*}$ & -3.2292 \\
& ECTt-1 & $-0.4131^{*}$ & -8.1881 \\
Argentina-Brazil & $\beta$ & $-0.0984^{*}$ & -1.3480 \\
& ECTt-1 & $-2.4205^{*}$ & -9.2791 \\
Brazil-Uruguay & $\beta$ & $-0.0141^{*}$ & -0.1763 \\
& ECTt-1 & $-0.5757^{*}$ & -8.0921 \\
Uruguay-Brazil & $\beta$ & $-0.2706^{*}$ & -3.3781 \\
& ECTt-1 & $-1.7369^{*}$ & -6.5465 \\
Argentina-Uruguay & $\beta$ & $0.6910^{*}$ & 0.8275 \\
& ECTt-1 & $-1.0126^{*}$ & -94.1640 \\
Uruguay-Argentina & $\beta$ & $-1.0498^{*}$ & -1.2651 \\
& ECTt-1 & $-0.9876^{*}$ & -93.1020 \\
\hline
\end{tabular}

Note: $(*)$ Indicates the significance level at $5 \%$.

Analysis of results identify small $\beta$ s for all Brazil equations. The rices markets weakly linked pairwise. Larger $\beta$ s for Uruguay and Argentina defining stronger links. The ArgentinaUruguay $\beta$ is positive.

The ECTs for Brazil and Argentina smaller than Brazil and Uruguay, pairwise. Brazil and Argentina rice markets weaker linked than Brazil and Uruguay.

Overall results show integrated rice spot markets but the degree, direction and signal vary. 
Tab. 5.Long run causality from Johansen VECM (weak exogeneity test).

\begin{tabular}{cccc}
\hline \multirow{2}{*}{ Model } & \multicolumn{2}{c}{ Causality test } & \multirow{2}{*}{ Causality decision } \\
\cline { 2 - 3 } & A & B & Brazil $\rightarrow$ Argentina \\
Brazil-Argentina & $0.3202(0.57)$ & $21.1947^{*}(0.00)$ & Brazil $\leftrightarrow$ Uruguay \\
Brazil-Uruguay & $17.6821^{*}(0.00)$ & $9.8982 *(0.00)$ & No causality \\
\hline Uruguay-Argentina & $1.6334(0.44)$ & $1.3260(0.51)$ & \\
\hline
\end{tabular}

Note: A indicates H0: $\alpha 1=0 \mathrm{vc}$. H1: $\alpha 1 \neq 0$. B indicates H0: $\alpha 2=0 \mathrm{vc}$. H1: $\alpha 2 \neq 0$.Parentheses indicate the probability level, where $(*)$ identifies the significance level at $5 \% . \rightarrow$ Indicates uni-directional causality. $\leftrightarrow$ Indicates bi-directional causality.

Therefore, results indicate that Brazil rice prices precedes Argentina, Brazil and Uruguay prices have bi-directional causality. Argentina and Uruguay rice prices have no causality. However, all results maybe due to the rice price level sampling, where Brazil rough rice was used, while Argentina and Uruguay it was white 5\% rice.

Second, basis risk and hedging effectiveness for rice market agents in the region was analyzed with a simulation framework using a hypothetical regional contract price.

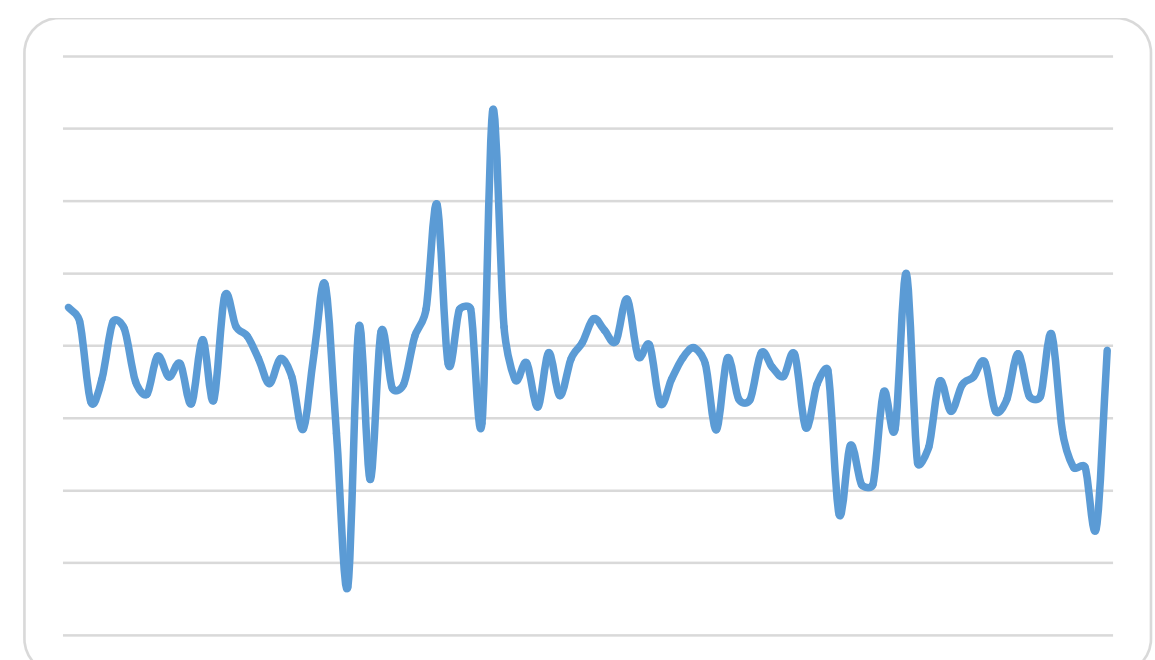

Graph 2. Brazil rice basis risk. Spot prices: Depressão Central (RS), futures price: CEPEA rice index. In US\$/ton. Jan 2006-Oct 2013

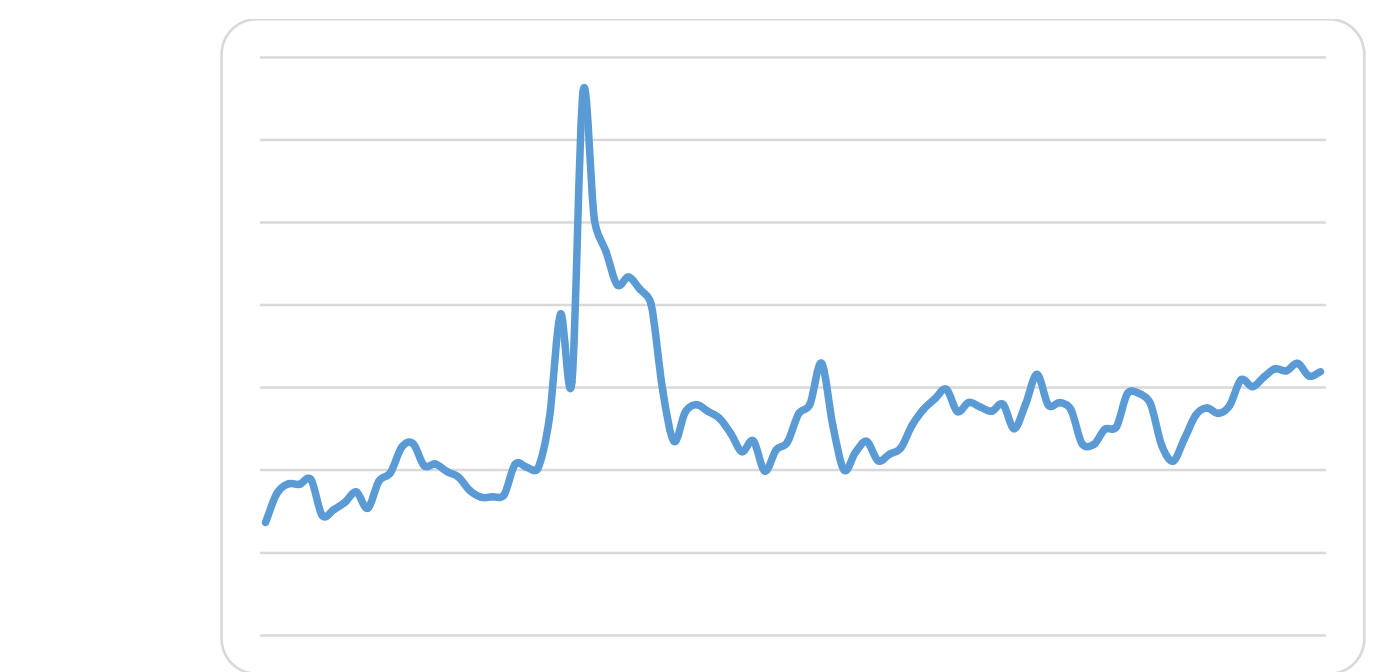

Graph 3. Uruguay rice basis risk. Spot prices: Uruguay FOB 5\%, futures price: CEPEA rice index.In US\$/ton. Jan 2006-Oct 2013

Souza, W. A. R.; Martines-Filho, J. G.; Zancan, C.; Costa, A. C. S.; Queiróz, A. G. A. 


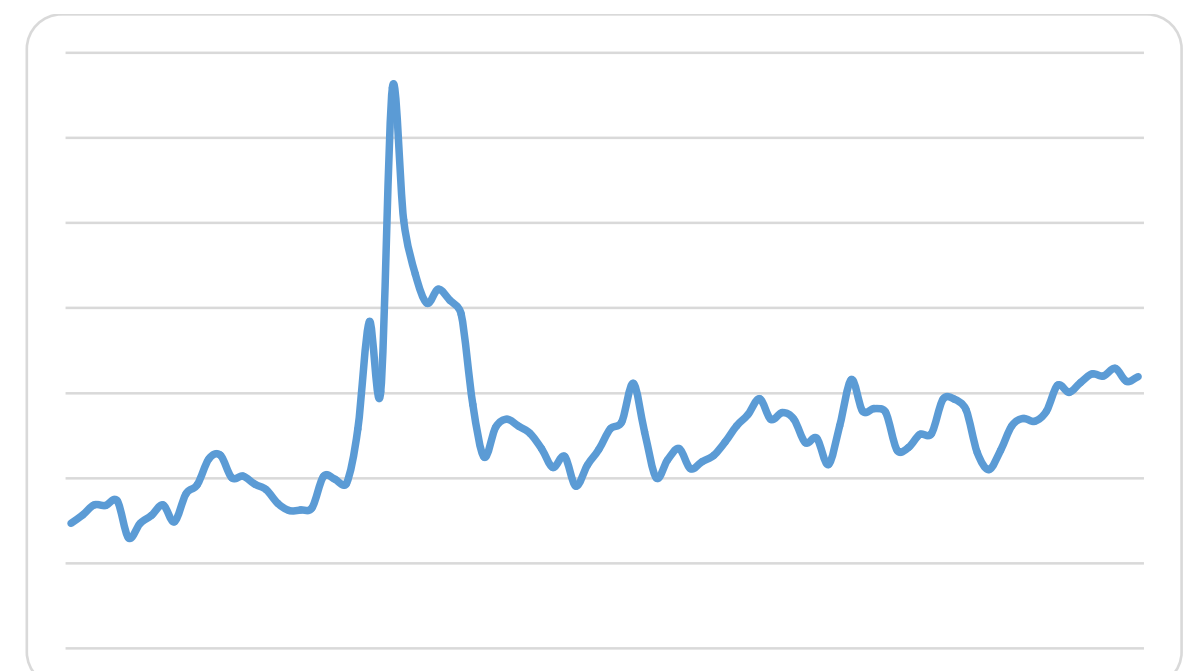

Graph 4. Argentina rice basis risk. Spot prices: Argentina FOB 5\%, futures price: CEPEA rice index. In US\$/ton. Jan 2006-Oct 2013

The analysis of Brazilian rice basis showed a seasonality pattern after the 2008 price shock. Furthermore, in Uruguay and Argentina the positive basis can be a result of the analyzed prices. There are not negative values, which are not robust results.

Tab. 6.Rice basis descriptives.

\begin{tabular}{|l|l|l|l|}
\hline Statistics & BR & UY & AR \\
\hline Average & $-1,91$ & 254,20 & 249,30 \\
\hline SD & 4,38 & 81,07 & 80,96 \\
\hline VC & $-2,3$ & 0,319 & 0,325 \\
\hline
\end{tabular}

Again Uruguay and Argentina show average positive values, which are not robust results. The variation coefficients for both countries are lower than Brazil, identifying comparatively more stable prices.

Finally, optimal hedge ratios and hedging effectiveness are expressed in Table 7:

Tab. 7.Mercosur rice prices.Optimal hedge ratio and hedging efficiency.

\begin{tabular}{|l|l|l|l|}
\cline { 2 - 4 } \multicolumn{1}{c|}{} & BR & UY & AR \\
\hline Variance UNHEDGED & 587,17 & 2461,90 & 2475,77 \\
\hline$H^{*}$ & 0,945 & 0,404 & 0,368 \\
\hline Variance HEDGED & 30,94 & 2360,00 & 2391,44 \\
\hline H Efficiency & $94,7 \%$ & $4,1 \%$ & $3,4 \%$ \\
\hline
\end{tabular}

Results express optimal hedge ratios are high for Brazil and low for Uruguay and Argentina. Same for hedging efficiency. Again, results can be attributed to the different price data used. To conclude, this is a preliminary study, using available data for various sources. As it further progresses, there will be updates.

\section{Conclusions}

The aim of the research was to investigate the feasibility of a Brazilian rice futures contract to serve the Mercosur region. The Mercosur rice price dynamics, linkages and, was 
estimated. Also, basis risk and hedging effectiveness for rice market agents in the region was analyzed, with a simulation framework using a hypothetical regional contract price.

In fact, previous literature demonstrated the feasibility for a rice futures contract in Brazil (CAPITANI, 2013; CAPITANI; MATTOS, 2013; COSTA ET AL, 2010). However, analogous studies showed that for the ASEAN nations a rice futures was not viable (MCKENZIE, 2012). In particular, for the Mercosur regions there are not specific studies.

Therefore, the research results are the first step towards evaluating the creation a regional rice futures contract for Mercosur, comprising the rice markets in Brazil, Argentina, Uruguay and Paraguay. In the long-term the Mercosur rice futures price dynamics could be leveraged into a global rice futures market, similar to the existing coffee and cocoa futures contracts trading in international exchanges, using multiple price and delivery schemes.

Furthermore, Mercosur rice price dynamics expressed Argentina and Uruguay rice prices moving in synchrony. Brazil rice prices were on lower levels. Also, all three pairs of rice price series are cointegrated, with one cointegrating equation. However, rice spot markets are integrated but the degree, direction and signal vary. Besides, results indicate that Brazil rice prices precedes Argentina, Brazil and Uruguay prices have bi-directional causality. Argentina and Uruguay rice prices have no causality.

In addition, the analysis of Brazilian rice basis showed a seasonality pattern after the 2008 price shock. Furthermore, in Uruguay and Argentina the positive basis can be a result of the analyzed prices. There are not negative values, which are not robust results.

Next, results express optimal hedge ratios are high for Brazil and low for Uruguay and Argentina. Same for hedging efficiency.

Again, results can be largely attributed to the different price data used, in Brazil was rough rice, while in Uruguay and Argentina milled white rice with 5\%. Despite that, there are preliminary evidences that a Mercosur rice futures market could be feasible.Moreover, a suggested outline for additional research about the Mercosur rice futures market feasibility could be:

To conduct an industry analysis to examine whether the necessary market conditions exist for a successful rice futures market in Mercosur. This analysis will identify potential contract users, and will determine if existing CME rice futures contract could meet the hedging needs of these users;

To design the potential Mercosur rice futures contract specifications and implementation steps. Additionally the implementation framework could be developed working closely with the futures exchange in Brazil, Argentina and USA; specific guidelines could outline issues such as the electronic double listing for simultaneous trading at different exchanges in Mercosur, rice futures contract specifications, market makers' role, speculators participation, industry agent catalyst, short side trading attraction and educational efforts.

In summary, the US rice futures contract spent 30 years until fruition, young compared with soybeans and corn futures. Besides the strict economic factors, some key elements for a futures markets to succeed are persistence, agents' commitment and education (HAMILTON, 2012). Particularly for the Mercosur rice futures market these elements must be present, creating the trading sphere necessary for spreading its economic benefits to the agents.

\section{References}

ADAMI, A. C. D. O; MIRANDA, S. H. G. D. Transmissão de preços e cointegração no mercado brasileiro de arroz. Revista de Economia e Sociologia Rural, v. 49, n. 1, p. 55-80, 2011. 
BEKKERMAN, A.; TEJEDA H. A. Revisiting the determinants of futures contracts: the curious case of Distillers' Dried Grains. Proceedings... St. Louis, MO, 2013. Available at: http://www.farmdoc.illinois.edu/nccc134. Access on 03.01.14.

BRANNEN, P. P.; ULVELING, E. F. Considering an informational role for a futures market.The Review of Economic Studies, v. 51, n. 1, p. 33-52, 1984.

BRORSEN, B. W.;FOFANA, N. F. Success and failure of agricultural futures contracts.Journalof Agribusiness, v. 19, n. 2, p. 129-145, 2001.

CAPITANI, D. H. D. Viabilidade de implantação de um contrato futuro de arroz no Brasil. 2013. Tese de Doutorado, Escola Superior de Agricultura Luiz de Queiroz, Universidade de São Paulo, Piracicaba, 2013. Acesso em 2014-01-01. Disponível em: <http://www.teses.usp.br/teses/disponiveis/11/11132/tde-15052013-102802/>

CAPITANI, D. H. D.; MATTOS, F. Developing new futures contract versus crosshedging: a study in the Brazilian rice market.Agricultural \& Applied Economics Association, Annual Meeting, poster, Washington D.C., 2013.

COSTA, A. A.;COELHO, A. B.;MIRANDA, S. H. G.; LÍRIO, V. S. Condições para implantação do contrato futuro de arroz no Brasil. AnáliseEconômica, v. 28, n. 54, p. 249$279,2010$.

CUNY, C. J. The role of liquidity in futures market innovations. Review Financial Studies, v. 6, n. 1, p. 57-78, 1993.

FINGER, M. I. F.;WAQUIL, P. D. Percepção e medidas de gestão de riscos por produtores de arroz irrigado na Fronteira Oeste do Rio Grande do Sul. Ciência Rural, v. 43, n. 5, p. 930936, 2013.

GRAY, R. W. Why does futures trading succeed or fail: an analysis of selected commodities. Food Research Institute. Stanford University. 1966. Downloaded at: http://www.farmdoc.illinois.edu/irwin/archive/books/Futures_Seminar_V3/Futures\%20Semin ar\%20V3_Gray2.pdf. Access on 03.01.14.

HAMILTON, M. A position paper on rice futures.2012. Downloaded at: http://www.rsis.edu.sg/nts/resources/db/uploadedfiles/SubmitttedPositionPaperonFutures.pdf. Access on 03.01.14.

HUNG, M. W.;LIN, B. H.; HUANG, Y. C.;CHOU, J. H. Determinants of futures contract success: empirical examinations for the Asian futures markets.International Review of Economics \& Finance, v. 20, n. 3, p. 452-458, 2011.

JOHNSTON, E. T.;MCCONNELL, J. J. Requiem for a market: an analysis of the rise and fall of a financial futures contract. Review Financial Studies, v. 2, n. 1, p 1-23, 1989.

LEUTHOLD, R. M. Evaluating futures exchanges in liberasing economies. DevelopmentPolicyReview, v. 12, p. 149-163, 1994. 
MARION FILHO, P. J.;EINLOFT, N. E. A Competitividade do Arroz Irrigado Brasileiro no Mercosul.OrganizaçõesRurais\&Agroindustriais, v. 10, n. 1, p. 11-22, 2008.

MCKENZIE, A. M. Prefeasibility Study of an ASEAN Rice Futures Market.ADB Sustainable Development Working Paper Series, v. 19, 2012.

MCKENZIE, A. M. et al. Unbiasedness and Market Efficiency Tests of the U.S. Rice Futures Market.ReviewofAgriculturalEconomics,v. 24, n. 2, p. 474-493, 2002.

MIRANDA, S. H. G.et al. O Sistema agroindustrial do arroz no Rio Grande do Sul. In. XLV Congresso da Sociedade Brasileira de Economia, Administração e Sociologia Rural.Anais...Londrina, PR, 2007.

MORGAN, C. W.;RAYNER, A. J.; VAILLANT, C. Agricultural futures markets in LDCs: a policy response to price volatility? Journal of International Development, v.11, n. 6, p. 893910, 1999.

OECD-FAO, Agricultural Outlook.Downloaded at: <http://www.oecd.org/site/oecdfaoagriculturaloutlook/database-oecd-faoagriculturaloutlook.htm>.Access on 10.10.13.

PECK, A. E. Economic role of traditional commodity futures markets.In: Anne E. Peck, Futures markets: their economic role, American Enterprise Institute for Public Policy Research: Washington, D.C., 1985, p.1-81.

The development of commodity exchanges in the former Soviet Union, Eastern Europe, and China. Australian Economic Papers, v. 40, p. 437-460, 2001.

PENNINGS, J. M. E.;LEUTHOLD, R. M. Introducing new futures contracts: reinforcement versus cannibalism. Journal of International Money and Finance, v. 20, p. 659-675, 2001.

QUINTINO, D. D.; DAVID, S. A. Quantitative analysis of feasibility of hydrous ethanol futures contracts in Brazil.Energy Economics, v. 40, p. 927-935, 2013.

SANDERS, D. R.;MANFREDO, M. R. The white shrimp futures market: lessons in contract design and marketing. Agribusiness, v. 18, n. 4, p. 505-522, 2002.

SANDOR, R. L. Innovation by an exchange: a case study of the development of the plywood futures contract.Journal of Law and Economics, v. 16, n. 1, p. 119-136, 1973.

SILBER, W. L. Innovation, competition, and new contract design in futures markets. The Journal of Futures Markets, v. 1, n.2, p.123-155, 1981.

SIQUEIRA, K. B.;SILVA, C. A. B.;AGUIAR, D. R. Viability of introducing milk futures contracts in Brazil: a multiple criteria decision analysis.Agribusiness, v.24, n. 4, p.491-509, 2008.

TASHJIAN, E. Optimal futures contract design. The Quarterly Review of Economics and Finance, v. 35, n. 2, p. 153-162, 1995. 
TELSER, L. G.; HIGINBOTHAM H. N. Organized futures markets: costs and benefits. The Journal of Political Economy, v. 85, n. 5, p. 969-1000, 1977.

WORKING, H. Economic functions of futures markets. Futures Trading in LivestockOrigins and Concepts, Chicago: Chicago Mercantile Exchange, p.267-297, 1970.

ZACHARIAS, T. P.et al.A producer-level cross-hedge for rough rice using wheat futures. Southern Journal of Agricultural Economics, v. 19, n. 2, p. 75-82, 1987. 